\title{
Zygmunt Kukuła, Przestępczość socjalna z perspektywy prawa karnego i kryminologii, Wyd. Difin, Warszawa 2016, ISBN 978-83-8085-231-0, ss. 289.
}

1.

Przestępczość socjalna nie jest zjawiskiem nowym, charakterystycznym tylko dla współczesnych organizacji państwowych, realizujących na szeroką skalę politykę bezpieczeństwa socjalnego' ${ }^{1}$. Pierwsze symptomy tego zjawiska pojawiły się w Europie Zachodniej bowiem już na początku XIX wieku, wraz z wprowadzeniem przez niektóre państwa instrumentów socjalnych, mających na celu wspieranie ludzi ubogich, pozbawionych źródeł utrzymania lub niebędących w stanie podjąć pracy². Na przestrzeni kolejnych stuleci, na skutek zachodzących zmian społeczno-gospodarczych następowało stopniowe zwiększenie zakresu zabezpieczenia socjalnego i rozbudowanie systemu świadczeń społecznych, które poza niezaprzeczalnymi korzyściami, niestety spowodowało także wzrost skali nadużyć w sferze

1 Zob. I. Sierpowska, Bezpieczeństwo socjalne jako dobro publiczne, „Zeszyty Naukowe Państwowej Wyższej Szkoły Zawodowej im. Witelona w Legnicy" 2015, nr 16(3), s. 45-58; L. Dziewięcka-Bokun, Bezpieczeństwo socjalne jako podstawa pokoju społecznego, [w:] J. Supermat (red.), Między tradycją a przyszłościq w nauce prawa administracyjnego, Księga jubileuszowa dedykowana Profesorowi Janowi Bociowi, Wrocław 2009, s. 132-142.

2 Z. Kukuła, Prawo karne wobec przestępczości socjalnej, „Studia Prawnoustrojowe UWM" 2010, nr 11, s. 311. 
Fabian Nalikowski - Z. Kukuła, „Przestępczość socjalna...”[rec.]

socjalnej, polegających przede wszystkim na niezgodnym z prawem wykorzystaniu środków publicznych.

W Polsce przestępczość socjalna pojawiła się stosunkowo niedawno, bo w zasadzie dopiero na początku lat dziewięćdziesiątych ubiegłego wieku, w związku z wprowadzeniem zasiłku dla bezrobotnych, a także szeregu innych zasiłków i świadczeń socjalnych, mających minimalizować negatywne skutki transformacji ustrojowej ${ }^{3}$. Z tych też względów przynajmniej początkowo nadużycia w sferze socjalnej były bagatelizowane, a nawet istniało społeczne przyzwolenie na tego rodzaju praktyki. Względnie szybko jednak przestępczość socjalna zaczęła odgrywać coraz istotniejszą rolę wśród różnych rodzajów przestępczości gospodarczej i stała się poważnym problemem społecznym. Wskazane zjawisko niewątpliwie będzie przybierać na sile także w kolejnych latach $\mathrm{w}$ związku z realizacją dużych programów społecznych absorbujących znaczne środki publiczne.

W tym kontekście szczególnego znaczenia nabiera problematyka związana z karnoprawną ochroną sektora świadczeń socjalnych państwa, która nie była dotychczas przedmiotem szczególnego zainteresowania zarówno ze strony prawa karnego, jak też kryminologii. W literaturze przedmiotu brak jest wszak opracowań monograficznych, które w całości byłyby poświęcone zjawisku przestępczości socjalnej, postrzeganej przez pryzmat prawa karnego sensu largo. Dlatego też podjęcie niniejszej problematyki w ramach recenzowanego opracowania zasługuje na uznanie i niewątpliwie stanowi istotny wkład w rozwój nauki prawa karnego. Posiada przy tym znaczenie nie tylko dla przedstawicieli nauki prawa karnego, ale również dla osób zawodowo związanych z różnymi instytucjami socjalnymi.

\section{2.}

Recenzowana monografia składa się z dwóch zasadniczych części: teoretycznej i empirycznej, które zostały poprzedzone wstępem i roz-

\footnotetext{
${ }^{3}$ M. Smoleń, Społeczne skutki transformacji ustrojowej $w$ wymiarze lokalnym, „Nierówności Społeczne a Wzrost Gospodarczy" 2006, nr 9, s. 283-284.
} 
działem poświęconym założeniom metodologicznym prowadzonych badań (rozdział I). W części teoretycznej opracowania przedstawiono istotę i charakter zjawiska przestępczości socjalnej (rozdział II), ustawodawstwo socjalne i instytucje socjalne (rozdział III), regulacje prawne stanowiące część ustawowego opisu znamion przestępstw (rozdział IV), a także typizację czynów zabronionych związanych z przestępczością socjalną, zawartych w Kodeksie karnym i przepisach pozakodeksowych (rozdział V). Natomiast w części empirycznej przybliżono czytelnikom zagadnienia związane $\mathrm{z}$ przestępczością ujawnioną przy dystrybucji środków z Państwowego Funduszu Rehabilitacji Osób Niepełnosprawnych (rozdział VI), jednostek organizacyjnych pomocy społecznej (rozdział VII), powiatowych urzędów pracy (rozdział VIII) i Zakładu Ubezpieczeń Społecznych (rozdział IX). W końcowej części pracy przedstawiono wnioski z przeprowadzonych badań (rozdział X) i propozycje zmian legislacyjnych (rozdział XI).

Struktura przedmiotowego opracowania jest logiczna, spójna i odpowiada założeniom badawczym przedstawionym we „Wstępie”, aczkolwiek pewien niedosyt - z przyczyn niezależnych od autora - może budzić nieuwzględnienie w badaniach Kasy Rolniczego Ubezpieczenia Społecznego. Ów niedostatek w materiale empirycznym powoduje bowiem, że przedstawiony obraz przestępczości socjalnej jest niepełny i nie obejmuje obszarów wiejskich, gdzie przestępczość socjalna także występuje. Wrażenie to dotyczy także przestępczości popełnianej za granicą, której szczegółowe omówienie przekraczałoby jednak ramy niniejszego opracowania (s. 64-66).

\section{3.}

Założenia badawcze przedstawione przez autora uwzględniają między innymi następujące zagadnienia:

(...) ujawnione przypadki przestępstw socjalnych w Polsce w okresie przemian ustrojowych; czynniki kryminogenne przestępczości socjalnej; wszelkie możliwe do zdobycia informacje o sprawcach przestępstw socjalnych; rodzaje świadczeń socjalnych będących przedmiotem zamachu sprawców; zjawisko przestępczości socjalnej za granicą" (s. 10). 
Fabian Nalikowski - Z. Kukuła, „Przestępczość socjalna...”[rec.]

Stosunkowo szeroko zakreślony obszar badań stanowi niewątpliwą zaletę recenzowanej monografii i pozwala na wszechstronną analizę tytułowego zagadnienia.

Punktem wyjścia w rozdziale I jest hipoteza badawcza, zgodnie z którą:

możliwe jest zidentyfikowanie zagrożeń przestępczością w odniesieniu do każdej z badanych instytucji socjalnych i wykazanie, że przestępczość występuje w każdej z nich (s. 19).

$\mathrm{Na}$ jej podstawie sformułowano szereg hipotez szczegółowych, w świetle których:

1) same instytucje socjalne potrafią zdiagnozować czynniki odpowiedzialne za występowanie przestępstw, 2) występowanie przestępstw jest rezultatem rozpoczętych zmian ustrojowych i w dużej mierze spowodowane jest występującym bezrobociem oraz spadającymi dochodami uzyskiwanymi przez obywateli polskich, 3) przestępczość socjalna wykazuje w sobie elementy wskazujące, że sprawcy działają $w$ ramach zorganizowanych struktur przestępczych, 4) jednostki organizacyjne pomocy społecznej usytuowane w małych miejscowościach nie notują przypadków przestępstw w takiej liczbie, jak w dużych miastach (s. 19-20).

Analizując powyższe założenia wydaje się, że supozycja przyjęta przez autora niniejszej publikacji, zgodnie z którą to same instytucje socjalne potrafią zdiagnozować czynniki odpowiedzialne za występowanie przestępstw może być zbyt optymistyczna. Przede wszystkim dlatego, że instytucje socjalne nie zawsze będą zainteresowane wskazywaniem tych czynników, które wynikają z niewłaściwego funkcjonowania tych jednostek, braku należytego nadzoru nad ich działalnością, udziałem pracowników w popełnieniu przestępstwa itd., znacznie chętniej będą natomiast wskazywać na przyczyny zewnętrzne, występujące po stronie sprawców przestępstw socjalnych (chęć uzyskania dodatkowego dochodu, bezrobocie) albo też wadliwość przepisów prawnych. Pozostałe hipotezy nie budzą wątpliwości. 
4.

Istotnym wkładem autora w rozwój nauki prawa karnego jest zdefiniowanie pojęcia przestępczości socjalnej jako:

(...) działania osób fizycznych w celu skłonienia instytucji socjalnej do określonego rozporządzenia mieniem oraz wyłudzenia nienależnym im świadczeń materialnych wyczerpujące znamiona przestępstwa, polegające na umyślnym wprowadzaniu w błąd lub wyzyskaniu błędu instytucji zajmujących się dystrybucją środków budżetowych, skierowanych wyłącznie na pomoc lub wsparcie materialne zarówno dla osób posiadających, jak i pozbawionych czasowo lub na stałe źródła utrzymania (s. 28).

Powyższa definicja w sposób zwięzły, a zarazem wyczerpujący prezentuje charakterystyczne cechy przestępczości socjalnej, wyróżniające ten rodzaj przestępczości na tle innych czynów zabronionych.

Czynnikiem utrudniającym badania nad zjawiskiem przestępczości socjalnej w Polsce, w szczególności zaś określenie skali tego zjawiska, jest brak danych statystycznych. W związku z powyższym konieczne jest wykorzystanie wszystkich dostępnych źródeł, w tym również publikacji prasowych, mając wszak na względzie, że „(...) nie spełniają wymogów stawianych przed rzetelnym badaniem naukowym, stąd też nie mogą stanowić podstawy do formułowania wiarygodnych ustaleń badawczych" (s. 29).

Należy jednak zgodzić się $\mathrm{z}$ autorem recenzowanej monografii, że stanowią one pewien materiał wyjściowy stanowiący „(...) bardzo istotne wskazówki co do kierunków dalszych poszukiwań, a w szczególności do pogłębiania i weryfikowania ustaleń badawczych" (s. 29).

W dalszej części niniejszego rozdziału zaprezentowano przegląd informacji prasowych opisujących ujawnione przypadki przestępczości socjalnej w Polsce i w Europie (s. 30-47). Ów przegląd obrazuje sposoby popełniania przestępstw socjalnych i kierunki przestępczości socjalnej. Wskazany jest jednak daleko idący krytycyzm naukowy w odniesieniu do informacji zawartych w publikacjach prasowych.

Na uwagę zasługuje także wskazanie w recenzowanej monografii czynników kryminogennych przestępczości socjalnej, do których 
Fabian Nalikowski - Z. Kukuła, „Przestępczość socjalna...”[rec.]

autor zalicza: czynniki generowane wadliwością systemu prawnego, czynniki z grupy społeczno-kulturowej, czynniki kryminogenne o podłożu ekonomicznym, a także nieskuteczność kary (s. 48-58). Szczególnie interesująco jawią się na tym tle czynniki natury ekonomicznej, które „(...) mogą kreować sytuację w których częściej może dojść do popełnienia przestępstw" (s. 55). Zaprezentowane podejście do tytułowego zagadnienia wskazuje na wszechstronną i wnikliwą analizę problemu. Poznanie przyczyn przestępczości pozwala bowiem skutecznie jej przeciwdziałać.

Ponadto ustalenia zawarte $\mathrm{w}$ rozdziale II zostały uzupełnione o przegląd zagrożeń dla systemu socjalnego państwa, sprawców przestępstw socjalnych i nadużyć w obszarze zabezpieczenia społecznego na szczeblu Unii Europejskiej. Ma to związek z koordynacją krajowych systemów zabezpieczenia społecznego. Wskazane uwagi niewątpliwie stanowią wartościowy fragment recenzowanej monografii, w kontekście zapobiegania przestępczości na szczeblu wspólnotowym.

W rozdziale III przedstawiono natomiast ustawodawstwo socjalne i instytucje socjalne korzystające z prawnokarnej ochrony. Tę część rozważań rozpoczyna niezbyt obszerny rys historyczny ustawodawstwa socjalnego w Polsce i w Europie (s. 67-71). Następnie przedstawiono poszczególne regulacje prawne dotyczące funkcjonowania Zakładu Ubezpieczeń Społecznych, Kasy Rolniczego Ubezpieczenia Społecznego, Powiatowych Urzędów Pracy, Miejskich Ośrodków Pomocy Społecznej i Państwowego Funduszu Rehabilitacji Osób Niepełnosprawnych.

$\mathrm{W}$ kolejnym rozdziale zaprezentowano przepisy zawarte $\mathrm{w}$ poszczególnych ustawach socjalnych w kontekście interpretacji ustawowych znamion wybranych typów przestępstw. Zawarte tam rozważania są o tyle istotne, gdyż, jak stwierdza autor:

Żadna z ustaw socjalnych nie zawiera przepisów karnych typizujących przestępstwa, każda z nich jednak posiada w swojej treści normy, które wprost bądź pośrednio zostają naruszone, stanowiąc jednocześnie część opisu ustawowych znamion konkretnego przestępstwa (s. 80). 
W tym sensie rzeczywiście omawiane normy prawne mają wiele wspólnego z normami sankcjonowanymi.

$\mathrm{W}$ rozdziale $\mathrm{V}$ przedstawiono typizację czynów stanowiących przestępstwa socjalne oraz czynów z nim związanych w przepisach karnych. Podkreśla się przy tym wyraźnie subsydiarne znaczenie prawa karnego w zakresie zwalczenia nadużyć w sferze socjalnej (s. 96-97). Prawo karne nie może bowiem być traktowane jako omnipotentny i wyłączny środek przeciwdziałający przestępczości gospodarczej, w tym również przestępczości socjalnej. W tym kontekście na uwagę zasługuje - jak podkreśla sam autor - arbitralny podział na przepisy o charakterze podstawowym i przepisy o charakterze uzupełniającym, wskazując przy tym, że kryterium podziału stanowi intensywność występowania konkretnych przestępstw, a także to czy dane przepisy penalizują czyny, które mogą być popełnione przede wszystkim przez świadczeniobiorców, czy też pracowników instytucji socjalnych (s. 94-95). Powyższe rozwiązanie w znaczący sposób odbiega od zasad respektowanych powszechnie na gruncie nauki prawa karnego, gdzie w ramach pozornego zbiegu przepisów ustawy wyróżnia się zasadę wyłączającą zastosowanie przepisu posiłkowego (subsydiarnego) przez przepis główny (lex primaria derogat legi subsidiariae) ${ }^{4}$. Może zatem powstać nieuzasadnione wrażenie, że przepisy socjalne o charakterze podstawowym derogują przepisy o charakterze uzupełniającym, podczas gdy powyższa systematyka odnosi się wyłącznie do intensywności występowania konkretnych przestępstw socjalnych.

Zgodzić należy się ze stwierdzeniem, że najczęściej stosowanym przepisem karnym przeciwdziałającym nadużyciom w sferze zabezpieczenia społecznego jest przepis kryminalizujący oszustwo klasyczne zawarty w art. $286 \S 1$ k.k. Autor słusznie przy tym wskazuje, że przyczyną „popularności” powyższego unormowania jest elastyczność treści ustawowych znamion czynu, dotyczących wprowadzenia w błąd oraz wyzyskanie błędu, które odgrywają niezwykle istotną rolę na

\footnotetext{
${ }^{4}$ L. Gardocki, Prawo karne, Warszawa 2006, s. 152-153.
} 
Fabian Nalikowski - Z. Kukuła, „Przestępczość socjalna...”[rec.]

gruncie przestępczości socjalnej (s. 98). W większości przypadków charakteryzują one bowiem sposób zachowania się sprawcy przestępstwa socjalnego.

\section{5.}

Przechodząc do części empirycznej należy wskazać, iż w tej części recenzowanej monografii skupiono się na przestępczości ujawnionej przy dystrybucji środków z Państwowego Funduszu Rehabilitacji Osób Niepełnosprawnych, jednostek organizacyjnych pomocy społecznej, powiatowych urzędów pracy i Zakładu Ubezpieczeń Społecznych. Struktura poszczególnych rozdziałów zawartych w tej części jest analogiczna. Obejmuje bowiem następujące zagadnienia: geografię zjawiska i skalę nadużyć, rodzaje popełnianych przestępstw, przedmiot zamachu, charakterystykę sprawców przestępstw, określenie wysokości szkód majątkowych spowodowanych przestępstwami, przyczyny przestępstw socjalnych, ocenę obowiązujących regulacji z punktu widzenia uszczelnienia przyznawania świadczeń, a także środków prowadzących do ograniczenia przestępstw socjalnych.

W toku prowadzonych badań autor zdołał wykazać, że najwięcej przestępstw socjalnych odnotowano w Polsce centralnej, najmniej zaś na Podlasiu. Przestępczość socjalną cechuje przy tym zmienna dynamika nasilenia w poszczególnych regionach (s. 252-253). Brak jest zatem wyraźnych tendencji w tym zakresie. Znamienne jest przy tym to, że poziom przestępczości socjalnej nie jest bezpośrednio związany z poziomem dochodów uzyskiwanych przez mieszkańców poszczególnych regionów. Z przedstawionych danych wynika także, iż najwięcej przestępstw zostało popełnionych na szkodę Zakładu Ubezpieczeń Społecznych, powiatowych urzędów pracy i ośrodków pomocy społecznych. Powyższa konstatacja jest oczywista, jeżeli wziąć pod uwagę wielkość środków publicznych, jakimi dysponują wskazane instytucje socjalne.

Gdy zaś chodzi o rodzaje popełnianych przestępstw, to w przypadku wszystkich badanych instytucji socjalnych na plan pierwszy wysu- 
wają się przestępstwa polegające na oszustwie, fałszowaniu dokumentów, składaniu nieprawdziwych oświadczeń oraz przywłaszczenia (s. 138, 163, 197, 227).

Pewien naukowy niedosyt może budzić natomiast brak szczegółowych informacji o sprawcach przestępstw socjalnych, obejmujących m.in. stan rodzinny, poziom wykształcenia, stopień poczytalności, a także informacje czy sprawca popełnił przestępstwo po raz pierwszy, czy po raz kolejny, które byłyby pożądane z punktu widzenia kryminologii. Ze zrozumieniem należy jednak przyjąć wyjaśnienia autora, że ów deficyt informacji wynika przede wszystkim z faktu, że instytucje społeczne nie dysponują szczegółowymi informacjami na ten temat (s. 254).

Z pewnym zaciekawieniem należy przyjąć informacje o relatywnie niewielkiej wysokości szkód majątkowych będących następstwem przestępstw deklarowanych przez instytucje socjalne. W świetle przedstawionych przez autora wyliczeń łączna kwota strat $\mathrm{z}$ tego tytułu wynosi bowiem ok. 54,8 mln zł (s. 255). Porównując tę sumę chociażby ze stratami spowodowanymi przestępstwami podatkowymi, liczonymi w miliardach złotych można odnieść wrażenie, że przestępczość socjalna nie stanowi istotnego problemu społecznego, który wymagałby interwencji prawnokarnej. To niewątpliwie mylne przekonanie może wynikać z faktu, że przestępczość ujawniona stanowi niewielką część rzeczywistej przestępczości socjalnej. Dlatego też należy podchodzić do oficjalnych danych pochodzących z instytucji socjalnych z pewną ostrożnością, mając wszak świadomość występowania względnie dużej tzw. ciemnej liczby przestępstw socjalnych.

Gwoli wyjaśnienia należy $\mathrm{w}$ tym miejscu podkreślić, że moim celem nie było podważenie wiarygodności przedstawionych danych, ale zwrócenie uwagi na problem stosunkowo niskiej wykrywalności przestępstw socjalnych. 
Fabian Nalikowski - Z. Kukuła, „Przestępczość socjalna...” [rec.]

6.

Przedstawione badania potwierdziły, że przestępczość socjalna występuje w każdej z badanych instytucji socjalnych. W tym znaczeniu przestępczość socjalna jest zjawiskiem powszechnym i nie ogranicza się wyłącznie do określonych instytucji czy konkretnych świadczeń. Natomiast trudno jest zweryfikować hipotezę, że to same instytucje socjalne potrafią zdiagnozować czynniki odpowiedzialne za występowanie przestępczości socjalnej, o czym była mowa już na wstępie. Wskazanie czynników kryminogennych w odniesieniu do tytułowej kategorii przestępstw jest utrudnione przede wszystkim z uwagi na niewielkie proporcje i dość znaczne rozbieżności w uzyskiwanych odpowiedziach (s. 260-261). Tylko częściowo została potwierdzona hipoteza, zgodnie z którą występowanie przestępstw jest rezultatem rozpoczętych zmian ustrojowych i w dużej mierze spowodowane jest występującym bezrobociem oraz spadającymi dochodami uzyskiwanymi przez obywateli. Na podstawie zgromadzonego materiału empirycznego autor nie zdołał potwierdzić, że bezpośrednimi przyczynami przestępczość socjalnej jest bezrobocie oraz spadające dochody ludności, choć niewątpliwie wskazane czynniki mają wpływ na pojawienie się nadużyć w sferze socjalnej. Ostatecznie nie zostało potwierdzone także to, że sprawcy przestępstw socjalnych działają według zorganizowanych struktur przestępczych. Potwierdzenia nie zyskała także hipoteza, w świetle której jednostki organizacyjne pomocy społecznej usytuowane w małych miejscowościach nie notują przypadków przestępstw w takiej liczbie, jak w dużych miastach. Być może ma to związek z niższym poziomem bezrobocia w dużych miastach.

Wydaje się przyczynami braku potwierdzenia niektórych hipotez badawczych jest niewystarczający materiał empiryczny. Przy tym nie można z tego powodu czynić zarzutu autorowi, który podjął działania mające na celu zgromadzenie możliwie obszernego materiału empirycznego. Zachowawczy stosunek do hipotez badawczych dowodzi, że autor dokonał rzetelnej i krytycznej analizy. 
Wreszcie, rezultatem badań nad zjawiskiem przestępczości socjalnej jest wypracowanie propozycji zmian legislacyjnych, których celem jest ograniczenie liczby popełnianych przestępstw socjalnych. Odnosząc się do postulowanych zmian, należy podkreślić, że na szczególną uwagę zasługuje rozważanie prawnych aspektów wprowadzenia czasowego zakazu korzystania ze świadczeń, z punktu widzenia zgodności powyższego rozwiązania z materią uregulowaną w Konstytucji RP i kształtu tych uregulowań w poszczególnych ustawach socjalnych. Autor stwierdza przy tym, że istnieje możliwość wprowadzenia bez narażania się na zarzut niezgodności powyższych uregulowań z Konstytucji RP. Opowiada się przy tym za administracyjnoprawnym charakterem postulowanych regulacji, wskazując, że:

(...) ograniczenie powinno dotyczyć maksymalnego okresu nie dłuższego niż 3 miesiące, jeżeli świadczeniobiorca nadal pozostawał będzie w sytuacji kwalifikującej go do otrzymania pomocy społeczne. Przyczyna ta odpadnie, gdy udowodnione zostanie, że był nielegalnie zatrudniony i otrzymywał z tego tytułu dochód (s. 265).

Przy tym możliwa jest również modyfikacja tego środka w postaci znacznego obniżenia przez określony czas należnego świadczenia (s. 266).

Za wartościowy należy uznać także postulat wprowadzenia statystyki obejmującej przynajmniej stwierdzone przypadki wypłaty nienależnych świadczeń, aczkolwiek będzie oznaczać to dodatkowe obciążenie instytucji socjalnych biurokratycznymi obowiązkami.

Pozytywnie należy również ocenić propozycję wprowadzenia jakiejś formy nadzwyczajnego złagodzenia odpowiedzialności karnej dla sprawców, którzy po ujawnieniu przestępstwa wyłudzenia świadczeń socjalnych, ale przed wszczęciem postępowania karnego dobrowolnie zwróciliby całość bezprawnie otrzymanej kwoty wsparcia. Wartym rozważenia postulatem jest także zmiana na zasadzie wyjątku przepisów regulujących warunkowe umorzenie postępowania karnego, tak aby z powyższej możliwości mogli skorzystać także sprawcy oszustwa, które w obecnym stanie prawnym zagrożone jest karą 
Fabian Nalikowski - Z. Kukuła, „Przestępczość socjalna...” [rec.]

pozbawienia wolności do lat 8 , a co za tym idzie niedopuszczalne jest stosowanie warunkowego umorzenia postępowania karnego wobec sprawców tych czynów. Wydaje się jednak, że ten problem można by rozwiązać także poprzez obniżenie w przypadku przestępstwa oszustwa górnej granicy ustawowego zagrożenia karą.

7.

Przedstawione w recenzowanej monografii wyniki badań, dotyczących problematyki przestępczości socjalnej, ukazanej z perspektywy prawa karnego i kryminologii, wskazują na wszechstronną i wyczerpującą analizę obowiązujących regulacji prawnych i zgromadzonego materiału empirycznego, dokonaną przez autora. Przedmiotowe opracowanie stanowi przy tym oryginalne rozwiązanie problemu badawczego, mające także znaczenie praktyczne. Krytyczne podejście Z. Kukuły do przyjętych założeń badawczych dowodzi rzetelności naukowej i obiektywizmu. Zrozumiały i przejrzysty sposób przekazu korzystnie wpływa na percepcję analizowanych zagadnień.

\section{Bibliografia:}

Dziewięcka-Bokun L., Bezpieczeństwo socjalne jako podstawa pokoju społecznego, [w:] J. Supermat (red.), Między tradycjq a przyszłościq w nauce prawa administracyjnego, Księga jubileuszowa dedykowana Profesorowi Janowi Bociowi, Wrocław 2009.

Gardocki L., Prawo karne, Warszawa 2006.

Kukuła Z., Prawo karne wobec przestępczości socjalnej, „Studia Prawnoustrojowe UWM" 2010, nr 11, s. 311-324.

Sierpowska I, Bezpieczeństwo socjalne jako dobro publiczne, „Zeszyty Naukowe Państwowej Wyższej Szkoły Zawodowej im. Witelona w Legnicy" 2015, nr 16(3), s. 45-58.

Smoleń M., Społeczne skutki transformacji ustrojowej w wymiarze lokalnym, „Nierówności Społeczne a Wzrost Gospodarczy” 2006, nr 9, s. 283-296. 